\title{
IDENTIFICATION OF FACTORS AFFECTING ELEMENTARY TEACHERS' ATTITUDES TOWARDS INCLUSION IN KOSOVO: THE ROLE OF DEMOGRAPHIC VARIABLES
}

\author{
Donika Koliqi ${ }^{1}$, \& Naser Zabeli ${ }^{2}$ \\ ${ }^{1}$ Doctoral Student, University of Prishtina/Faculty of Education (Kosovo) \\ ${ }^{2}$ Professor at the University of Prishtina/Faculty of Education (Kosovo)
}

\begin{abstract}
Inclusion is at the center of interest of international institutions and associations and is considered as one of the main challenges facing education systems worldwide. According to different studies for the implementation of inclusive practices, positive attitudes of teachers are essential in the successful implementation of this change in education. The aim of this paper was to research the elementary teachers' attitudes towards inclusive education and to identify factors that influence their attitudes, such as: gender, age, training for inclusive education, level of education, educational experience, and experience with children with special needs. The methodology of the study is quantitative method. The population of this study include teachers of elementary level of education in the Kosovo and the sample include 300 respondents, who were surveyed with the Teachers' Attitudes towards Inclusion Scale (TAIS). The research findings have shown that the attitudes of primary school teachers towards inclusive education are below the neutral middle point. The findings have confirmed that the demographic variables have a moderate impact on teachers' attitudes, too. A slightly higher impact is noticed while they have been part of trainings and their experience on working with students, who are considered with special needs has also helped in raising awareness.
\end{abstract}

Keywords: Students with special needs, inclusive education, teacher attitudes, demographic variables.

\section{Introduction}

The inclusion of children with special educational needs in regular school institutions has been a global movement for at least three decades (Amor, et al., 2019). A special contribution to the conception of inclusive education was made by The Salamanca Declaration (UNESCO, 1994) according to which, the inclusive education is a form of education that provides access, support and effective education to students with special educational needs in regular schools while being included in activities with their peers.

Currently, inclusive education remains a major challenge of education systems (Sharma, Loreman, \& Forlin, 2011) and it is considered a central point in the educational agendas of different countries (Muntaner, Rosselló, \& de la Iglesia, 2016). This practice has influenced the reform of educational policies, however they have failed to guarantee the inclusion of all children with special needs (Peters, Johnstone, \& Ferguson, 2005). The full implementation of inclusive education depends on several preconditions. According to Ainscow and Sandill (2010) one of the most important dimensions in developing inclusive schools is the attitudes of factors towards diversity. Furthermore, key factors in the implementation of policies and the implementation of inclusive practices have been assessed by teachers, especially their attitudes towards inclusive education (UNESCO, 2009).

Numerous scientific researches have shown that teachers' attitudes determine the successful implementation of inclusive education (Saloviita \& Schaffus, 2016; Saloviita, 2018; Avramidis \& Norwich, 2002). Therefore, the teacher's pedagogical preparation is not considered to be enough, as it is also expected the positive attitude towards inclusive education. This has been proved by the conducted research in which 8200 children with special needs have been part of it in Germany, who have succedded more with teachers who have had more positive attitudes, in contrast to other students who have not succeeded as a result of teachers' negative attitudes towards their inclusion (Van der Veen, Smeets, $\&$ Derriks, 2010).

Attitudes are defined as "an individual's disposition to react to a certain degree in favor or disadvantage to an object, behavior, person, institution or event, or to any other discriminatory aspect of his or her individual world" (Ajzen, 1993, p. 41). According to Eagly and Chaiken (1993) attitudes consist of cognitive, affective and conative elements. Taking into account the teachers' attitudes towards 
inclusive education, the cognitive component includes positive or negative statements towards inclusive education, the affective component represents the emotional connection with inclusive values, and the conative component represents teachers' approach based on their beliefs and knowledge about inclusiveness (Saloviita, 2018).

According to Czyż (2018) the intensity and orientation of the attitude depends on several factors. Researches have identified several variables that impact teaching attitudes such as: gender, age, country, experience on working with children with special needs, work experience, vocational training, training regarding inclusive education. Studies, in which, gender has been researched, female teachers have dominated with more positive attitudes towards inclusive education compared to male teachers (Alquraini, 2012).

Regarding age, researches have shown that younger teachers have more positive attitudes than the older ones (Ahmmed, Sharma, \& Deppeler, 2014). According to Stoiber, Gettinger and Goetz (1998) the higher the professional preparation of teachers, specifically when talking about, the educational level, it is noted a positive tone regarding their attitudes towards inclusive education. One of the most influential factors in the positive attitudes of teachers according to research is attending trainings about inclusive education (Avramidis \& Norwich, 2002; Ahsan, Sharma, \& Deppeler, 2012). According to Beh-Pajooh (1992) among other details, teachers who have attended training for children with special needs are emotionally attached to them, unlike their counterparts who have not attended such training. Also, teachers with less than 14 years of experience have more positive attitudes towards the integration of students with special needs than those with more than 14 years of work experience (Leyser, Kapperman, \& Keller, 1994). As another important factor in attitudes towards inclusiveness is the contact and work with children with special needs (Saloviita, 2018), so teachers with more contact and work experience with children with special needs have more positive attitudes.

Based on the importance of recognizing the impact of factors, this research aims to identify teachers' attitudes towards inclusive education. In the meantime, it aims to identify the demographic factors that influence the attitudes of primary level teachers.

\section{Methodology}

In this study, there was used the quantitative method. This approach has enabled the reflection of teachers' current attitudes towards inclusive education and the identification of factors that have implicated their attitudes.

\subsection{Procedure}

Initially, permission to contact and teachers' e-mail addresses were obtained from Municipal Education Directorates in seven towns and then school principals were informed, too. The e-mail which was sent to the teachers contained information about the study as the research tool was placed in Google Forms format. A total of 500 emails were sent to teachers, while the forms were completed by 300 teachers to an account on Google Forms.

\subsection{Instruments for data collection}

The data collection tool was The Teacher Attitude towards Inclusive Education Scale" (TAIS) which is a degree that has achieved reliability up to $a=.90$ (Saloviita, 2015). "The scale included items on expected outcomes, rights of the child, teacher workload and inclusion as a value" (Timo \& Simone, 2019, p. 9). This instrument consists of 10 statements with five Likert scale answers: I completely disagree, I disagree, I am neutral, I agree and I completely agree. Part of the instrument were also 15 demographic questions.

\subsection{Participants}

Participants in this study were 300 primary school teachers from grades 1-5, part of public schools in Kosovo. Out of the total number of teachers $(\mathrm{N}=300), 90.33 \%(\mathrm{~N}=271)$ were females and $9.67 \%(\mathrm{~N}=29)$ males. Whereas, the average age of theirs was 45 , and the teaching experience average was 17 years. It is important to mention that the sample was unintentional.

\section{Results}

Descriptive and correlative statistical analyzes were used to identify teachers' attitudes and the influence of demographic factors on teachers' attitudes towards inclusive education. Based on the data, the attitudes of primary level teachers with the TIAS scale resulted (average $=26.6$ ) below the grade point average (average $=30.0)($ Table 1$)$. 
Table 1. Attitudes of teachers towards inclusive education as measured by "The Teacher Attitude towards Inclusive Education Scale" (TAIS).

\begin{tabular}{lrrrrrr}
\hline Elementary teacher & $\mathrm{N}$ & Mean & $\mathrm{SD}$ & $\mathrm{df}$ & $\mathrm{F}$ & $\mathrm{p}$ \\
\hline Sum total & 300 & 26.69 & 7.12 & 2,1644 & 60.12 & .000
\end{tabular}

Based on the data in TAIS, female teachers $(\mathrm{N}=271)$ had more positive attitudes in comparison to male teachers $(\mathrm{N}=29), \mathrm{t}(1,635)=3,59, \mathrm{p}=.000$ and with a slight differentiation $\mathrm{d}=.20$. In terms of age, teachers under the age of $30(\mathrm{~N}=97)$ were more positive than those over the age of $50(\mathrm{~N}=121)$, respectively with a statistically significant difference with $\mathrm{t}(181,233)=2,11$ and $\mathrm{p}=0.001$. Therefore, younger teachers were slightly more positive as opposed to older ones $(\mathrm{d}=.28)$. The results have shown that teachers with work experience under 15 years $(\mathrm{N}=179)$ were slightly more positive than teachers with more than 25 years of work experience $(\mathrm{N}=98)$, with $\mathrm{t}(1,523)=2,26, \mathrm{p}=0.031$. Thus, the most experienced teachers in education had slightly more positive attitudes compared to the less experienced teachers $(\mathrm{d}=.21)$. Based on the results, the educational level turns out to be statistically significant $\mathrm{t}(2,151)=3,22$ and $\mathrm{p}=.001$, respectively the teachers with the completed master level $(\mathrm{N}=211)$ were slightly more positive in contrast to the teachers who have completed only the bachelor level $(\mathrm{N}=89)$, with $(\mathrm{d}=.23)$. Teachers who attended more than three trainings for inclusive education $(\mathrm{N}=163)$ were more positive than their counterparts who have attended only one training $(\mathrm{N}=97)$, with $\mathrm{t}(2,675)=4,21$, $p=0.021$ and with an effect $d=1.38$. 10 years of experience of teachers working with children with special educational needs $(\mathrm{N}=120)$ have shown more positive attitudes than teachers with experience less than 5 years $(\mathrm{N}=86)$, with $\mathrm{t}(3,866)=5,18$ and with $\mathrm{p}=0.053$. More experienced teachers felt more positive than less experienced teachers with children with special needs with $d=1.42$.

\section{Discussion and conclusions}

This study has surveyed the Kosovar primary school teachers' attitudes towards inclusive education. The influence of some demographic variables on their attitudes was also investigated. The research results have showed that the attitudes of primary school teachers towards inclusive education are below the neutral middle point, similar to the results of other research where teachers were neutral or even indifferent (Ross-Hill, 2009; Czyż, 2018). Whereas, in terms of the demographic variables impact, female teachers were more positive than male teachers (e.g. Ahsan, Sharma \& Deppeler, 2012), younger teachers resulted in slightly more positive attitudes than older teachers (eg Saloviita, 2020), teachers with less teaching experience were slightly more positive than those with more teaching experience (e.g. Marshall, Ralph, \& Palmer, 2002), teachers with higher education level were more positive compared to those with lower education level (e.g. Stoiber, Gettinger, \& Goetz, 1998). As the variable with slightly greater impact turned out to be the largest number of trainings for inclusive education and years of experience with children with special needs (e.g. Majoko, 2017).

According to these findings, it can be concluded that it is important for teachers to attend trainings on inclusive education and having experience with children with special needs. They constantly need evolving in a professional perspective to change attitudes towards inclusive education. On the other hand, it is also important for every teacher to have contact and then face working with children with special educational needs, given that experience changes their negative or neutral attitudes. This professional development of teachers and this challenging experience is possibly going to affect the quality of teaching, considering the fact that each student should be supported no matter how different from the other, both in terms of skills and educational needs.

\section{References}

Ahmmed, M., Sharma, U., \& Deppeler, J. (2014). Variables affecting teachers' intentions to include students with disabilities in regular primary schools in Bangladesh. Disability \& Society, 29(2), 317-331. doi:10.1080/09687599.2013.796878

Ahsan, M. T., Sharma, U, \& Deppeler, J. M. (2012). Exploring pre-service teachers' perceived teaching-efficacy, attitudes and concerns about inclusive education in Bangladesh. International Journal of Whole Schooling, 8, 1-20. Retrieved from http://www.wholeschooling.net/ Journal_of_Whole_Schooling/articles/8-2\%20Ahsan\%20et\%20al.pdf

Ainscow, M., \& Sandill, A. (2010). Developing Inclusive Education Systems: The Role of Organisational Cultures and Leadship. International Journal of Inclusive Education 14(4), 401-416. doi:10.1080/13603110802504903 
Ajzen, I. (1993). Attitude Theory and the Attitude-Behavior. In D. Krebs, \& P. Schmidt, New Directions Measurement (pp. 41-57). Berlin-New York: Walter de Gruyter.

Alquraini, T. A. (2012). Factors related to teachers' attitudes towards the inclusive education of students with severe intellectual disabilities in Riyadh, Saudi. Journal of Research in Special Educational Needs, 12(3), 170-182. doi:10.1111/j.1471-3802.2012.01248.x

Avramidis, E., \& Norwich, B. (2002). Teachers' attitudes towards integration/inclusion: A review of the literature. European Journal of Special Needs Education, 17(2), 129-147. doi:10.1080/08856250210129056

Beh-Pajooh, A. (1992). The effect of social contact on college teachers' attitudes towards students with severe mental handicaps and their educational integration. European Journal of Special Needs Education, 7, 231-236. doi:10.1080/0885625920070201

Czyż, A. (2018). An Analysis of Polish Teachers Attitudes towards Inclusive Education. Future Human Image, 10, 4-19. doi: 10.29202/fhi/10/1

Eagly, A. H \& Chaiken, S. (1993). The psychology of attitudes. Fort Worth, TX: Harcourt, Brace Jovanovich.

Leyser, Y., Kapperman , G., \& Keller, R. (1994). Teacher attitudes toward mainstreaming: a cross-cultural study in six nations. European Journal of Special Needs Education, 9, 1-15. doi:10.1080/0885625940090101

Majoko, T. (2017). Inclusion in Early Childhood Education: a Zimbabwean perspective. International Journal of Inclusive Education, 21(12), 1210-1227. doi: 10.1080/13603116.2017.1335354

Marshall, J., Ralph, S., \& Palmer, S. (2002). 'I wasn't trained to work with them': Mainstream Teachers' Attitudes to Children with Speech and Language Difficulties. International Journal of Inclusive Education 6(3), 199-215. doi: 10.1080/13603110110067208

Muntaner, J. J., Rosselló, R. M., \& de la Iglesia, B. (2016). Buenasprácticas en educación inclusiva. [Good practices in inclusive education]. Educatio Siglo XXI 34(1), 31-50. doi:10.17811/rifie.46.2017.49-56

Peters, S., Johnstone, C., \& Ferguson, P. (2005). A disability rights in education model for evaluating inclusive education. International Journal of Inclusive Education, 9, 139-160. doi:10.1080/1360311042000320464

Ross-Hill, R. (2009). Teacher Attitude Towards Inclusion Practices and Special Needs Students. Journal of Research in Special Educational Needs 9, 188-198. doi: 10.1111/j.1471-3802.2009.01135.x

Saloviita, T. (2015). Measuring pre-service teachers' attitudes towards inclusive education: Psychometric properties of the TAIS scale. Teaching and Teacher Education, 52, 66-72. doi:10.1016/j.tate.2015.09.003

Saloviita, T. (2018). Attitudes of Teachers Towards Inclusive Education in Finland. Scandinavian Journal of Educational Research. doi:10.1080/00313831.2018.1541819

Saloviita, T. (2020). Teachers' Changing Attitudes and Preferences around Inclusive Education. International Journal of Disability, Development and Education. doi: 10.1080/ 1034912X.2020.1828569

Saloviita, T., \& Consegnati, S. (2019). Teacher attitudes in Italy after forty years of inclusion. British Journal of Special Education, 46(4), 465-479. doi: 10.1111/1467-8578.12286

Saloviita, T., \& Schaffus, T. (2016). Teacher attitudes towards inclusive education in Finland and Brandenburg, Germany and the issue of extra work. European Journal of Special Needs Education, 31(4), 458-471. doi:10.1080/08856257.2016.1194569

Sharma, U., Loreman, T., \& Forlin, C. (2011). Measuring teacher efficacy to implement inclusive practices. Journal of Research in Special Educational Needs, 12(1), 12-21. doi:10.1111/j.14713802.2011.01200.x

Stoiber, K. C., Gettinger, M., \& Goetz, D. (1998). Exploring Factors Influencing Parents' and Early Childhood Practitioners Beliefs about Inclusion. Early Childhood Research Quarterly 13(1). 107-131. doi: 10.1016/S0885-2006(99)80028-3

United Nations Educational, Scientific and Cultural Organisation (UNESCO). (1994, June 7-10). The Salamanca statement and framework for action on special needs education. Salamanca: World Conference on Special Needs Education: Access and Quality

United Nations Educational, Scientific and Cultural Organisation (UNESCO). (2009). Policy guidelines on inclusion in education. Paris: Author.

van der Veen, I., Smeets, E., \& Derriks, M. (2010). Children with Special Educational Needs in the Netherlands: Number, Characteristics and School Career. Educational Research 52(1), 15-43. doi:10.1080/00131881003588147 